\title{
Pneumatology and Politics: The role of the Holy Spirit in the articulation of an Orthodox political theology
}

\author{
NikOlaos Asproulis ${ }^{*}$
}

In this paper an attempt is made to discuss the importance of the Holy Spirit in the development of an Orthodox political theology, by bringing into critical dialogue the recent contributions of two of the most known Orthodox theologians of the young generation, namely A. Papanikolaou and P. Kalaitzidis. It is commonly recognized that the Holy Spirit is closely related both to the very "constitution of the whole Church" in virtue of the Eucharistic event, as well as to the everyday charismatic lives of individual Christians due to the various forms or stages of ascetism. In this respect a careful comparative examination of these two important works, would highlight some invaluable elements (Eucharistic perspective, eschatological orientation, historical commitment, ethical action, open and critical dialogue with modernity etc.) toward a formulation of a comprehensive and urgently necessary political theology. This sort of political theology should have inevitable implications for the Christian perception of the communal and the individual ecclesial life. This "theo-political" program proposed by the two thinkers and founded on a robust Pneumatology, could be perfectly included, following the apostolic kerygma and the patristic ethos, into a new way of doing (Orthodox) Christian theology, that takes as its starting point the grammar of the self-Revelation of God in the ongoing history of salvation ("Church and World Dogmatics").

Keywords: Pneumatology, orthodox political theology, communion, eschatology, public sphere

\section{Introduction}

It was commonplace ${ }^{1}$ until recent times that Orthodox theology in particular= had nothing to do at all with politics or social issues, due to its supposed meta-historical and liturgical dimension, while this political attitude was attributed explicitly to various trends of Western theology (i.e. liberation theology, theology of hope, etc) ${ }^{2}$ characterized by a more profound historical

\footnotetext{
* Nikolaos Asproulis, Volos Academy for Theological Studies, ABD Volos Academy for Theological Studies, Journal Theologia, Nelcee Coordinator. Adress: 16, Kriton Str., Athens-Greece, P.O 11744; e-mail: asprou@acadimia.gr, florovskian@gmail.com

1 See the relative discussion about "why has orthodoxy not developed a political or liberation theology" in Pantelis Kalaitzidis Orthodoxy and Political theology, WCC Publications, Geneva 2012, p. 65-80.

2 For a very comprehensive and detailed overview of the various theological trends in western tradition see: Rosino Gibellini, La teologia del XX secolo, Brescia ${ }^{4} 1999$. Especially on political theology see: Elizabeth Phillips, Political theology. A Guide for the Perplexed, Blooms-
} 
commitment. ${ }^{3}$ At the same time, however, since our Lord Jesus Christ assumed the fullness of the human nature (and person), that is the full human being, this necessitates that the Church also assume every aspect of human life (social, political, existential needs, etc) and of the Creation towards the fulfillment of its telos, that is its transformation to the "New Creation" in the Kingdom. This fundamental theological assumption led some important 20th century Western theologians and voices (i.e. J.B. Metz, J. Moltmann, D. Solle, G. Gutierrez, L. Boff etc.) to work and develop various forms of a political theology (i.e. Liberation theologies, theology of hope, etc.) which would take seriously the political dimension of the public life, ${ }^{4}$ bringing Christianity into constant and creative dialogue with post-modernity. At the same time, Orthodoxy, due mainly, but not exclusively, to historical reasons, reluctantly or suspiciously encountered this opening of the Western theologies to the modern challenges. Orthodoxy rendered itself incapable of yet developing a comprehensive political theology, despite the sporadic elements of political thought that one could trace within the patristic tradition such as Eusebius of Caesarea or Augustine. 5

This situation notwithstanding, 2012 was a real landmark year for modern Orthodox theology. Two quite promising books written by Prof. Aristotle Papanikolaou (Fordham University, New York, USA) ${ }^{6}$ and Dr. Pantelis Kalaitzidis (Volos Academy for Theological Studies, Greece) ${ }^{7}$ carved a new

bury 2012; William Cavanaugh et al. (eds.) An Eerdmans Reader in Contemporary Political theology, Eerdmans 2012; Peter Scott, W. Cavanaugh (eds.), The Blackwell Companion to Political Theology, Blackwell 2004.

3 On this distinction between the meta-historical attitude of the East and the historical commitment of the West see among others John Zizioulas "Eschatology and History" in: Thomas Wieser (ed.) Cultures in Dialogue: Documents from a Symposium in Honor of Philip A. Potter (WCC: Geneva, 1985) 30-39.

4 There is a debate in nowadays about the relationship between the "political theology" to "public theology", regarding the most adequate expression of the heart of Christian mission. See: Martin R. Levesque, Political Theology Versus Public Theology: Reclaiming the Heart of Christian Mission, Mth. Thesis, University of Western Ontario (2014).

5 See on this among others Aristotle Papanikolaou, The Mystical as Political. Democracy and non Radical Orthodoxy, Indiana 2012, p. 13-54; Sophie Lunn- Rockliffe, Ambrosiaster's political theology, Oxford, 2007; Allen Brent, A Political history of Early Christianity, Bloomsbury 2009; Ovidiu Panaite, "The Theological background of political philosophy in early Christianity-An essay on Orthodox Political theology" in: International Journal of Orthodox theology 4:1 (2013), p. 127-149.

6 A. Papanikolaou, The Mystical as Political. Democracy and non Radical Orthodoxy, Indiana 2012.

7 P. Kalaitzidis, Orthodoxy and Political theology, Doxa and Praxis, WCC Publications, Geneva, 2012. 
path in modern Orthodox theology, attempting to develop or better describe the necessary parameters or basic aspects of what an Orthodox political theology would look like. Based on a brief and introductory comparison of these two books, an attempt will be made in this paper to explore the relevance of a theology of the Holy Spirit, namely a Pneumatology, as it is understood in the Orthodox dogmatic tradition, for the development of a political theology and then describing some of the important dimensions that Pneumatology would offer towards this direction.

Before diving into both works, some preliminary remarks are necessary so as to clarify our point of departure and explain the way that the key concepts of our topic are understood. It is not the purpose of this article to present an overview of the history of political theology. Although one could find today many scholarly books dealing with the diverse aspects and trends of the political theology in the Christian tradition, from the biblical narrative (i.e. the case of Jesus himself or Paul $)^{8}$ through the patristic and scholastic theology until recent times, the term seems to have been used first by Carl Schmitt in his book of the same title in 1922. ${ }^{9}$ During the first half of the $20^{\text {th }}$ century, the encounter of Christianity with the emerging Marxist and Nationalist ideologies led some Christian theologians of different attitudes and perspectives to examine the way that Christian theology could understand or conceptualize the political dimension. Despite the preliminary attempt of Schmitt towards this perspective, afterwards the term "political theology" was closely linked to the well-known Roman Catholic theologian Johann Baptist Metz, who presented the basic axes of his new theological proposal in the 60s. According to his understanding, the basic aim of political theology is "to render Christian discourse socially effective." This way of reflection should not be understood as a sort of an idealization of a specific kind of political ideology or that theology is obliged to undertake or follow a particular political (left or right) agenda, but mainly as an enterprise to address from the perspective of the Christian Gospel the current social and political challenges by a creative, socially oriented, and effective way. This new perception of theology would be developed in diverse perspectives by eminent theologians such as Jurgen Moltmann, the Liberation theologians of Latin America and others. ${ }^{10}$ Ac-

8 See for instance Jacob Taubes, The Political Theology of Paul, Redwood City 2003; John Howard Yoder, The Politics of Jesus, Grand Rapids 1994.

9 Carl Schmitt, Political Theology: Four Chapters on the Concept of Sovereignty, trans. G. Schwab, Cambridge 1985, (1 $1^{\text {st }}$ German edition, 1922). See also the analysis in P. Kalaitzidis Orthodoxy and Political Theology, p. 15.

10 See for details Rosino Gibellini, La teologia del XX secolo, Brescia ${ }^{4} 1999$, chapters 9, 10, 12. 
cording to my understanding at least, the basic tenets of a political theology are its main focus on the public ${ }^{11}$ orientation of Christian theology, in a way that promotes and cultivates a new way of being based on freedom from any authoritarian form and love as solidarity to the other, and on the active engagement that overcomes the metaphysical speculation which ignores the real history and the social and political factors that forge human life. In short, one could describe political theology ${ }^{12}$ as a new attempt put forth by the various Christian theologians to address the challenges and the problems of (post) modernity, a sort of a contextual reading and interpretation of the Christian tradition in light of the existential and current needs of humanity, as implied in relation to the language of human rights, the relationship of the Church to the state, and so on.

On the other hand, our conception of pneumatology is that of Orthodox dogmatic theology, albeit not in a confessional manner, as particularly presented and interpreted by Metropolitan John Zizioulas, ${ }^{13}$ where the Holy Spirit, without being separated from the other Trinitarian persons, plays a special role in the divine economy, namely to constitute Christ as a communion event in history (pneumatologically constituted Christology), that is as the Body of Christ, as the Church, and bring into history the foretaste of the eschatological divine Kingdom. In this perspective the communal and eschatological dimension are two of the basic aspects of a theology of the Holy

11 For the definition and meaning of the concept "public sphere" see: Jürgen Habermas "The Public Sphere: An Encyclopedia Article (1964)" in: New German Critique, No. 3. (Autumn, 1974), p. 49-55; idem, The Structural Transformation of the Public Sphere. An inquiry into a category of Bourgeois society, trans. Th. Burger, Cambridge 1991; see also the critical discussion in Simon Susen, "Critical Notes on Habermas' theory of the Public Sphere" in: Sociological Analysis 5:1 (2011), p. 37-62.

12 This understanding of the concept of "political theology" does not necessarily depend on the various understandings of this concept by the main stream political theologies although it takes into account or draws implicitly on these.

13 See for instance Zizioulas's Being as Communion: Studies in Personhood and the Church, Crestwood-New York, 1985; idem, in: Paul McPartlan (ed.), Communion \& Otherness, London 2006; idem, "The Holy Spirit and the Unity of the Church-An Orthodox Approach" in: D. Donnelly, A. Denaux et al. (eds.), The Holy Spirit, the Church and the Christian Unity, Leuven 2005, p. 35-46; idem, "Come, Holy Spirit, Sanctify our lives" in: Sourozh 44 (1991) p. 1-3; idem "Implications ecclésiologiques de deux types de pneumatologie" in: Communio Sanctorum, Editions Labor et Fides : Geneva, 1981, p. 141-154; idem "Cristologia, pneumatologia e istituzioni ecclesiastique: un punto di vita ortodosso" in: Cristianesimo nella storia 2 (1981), p. 111-127. See also: Eléni Pavlidou, Cristologia e pneumatologia: tra Occidente cattolico e Oriente ortodosso neo-greco: per una lettura integrata di W. Kasper e J. Zizioulas in prospettiva ecumenica, Roma, 1997; Jerry Skira Zenon, Christ, the Spirit and the Church in modern Orthodox theology: a comparison of Georges Florovsky, Vladimir Lossky, Nikos Nissiotis and John Zizioulas, Toronto 1998. 
Spirit, as described in the Bible and manifested in the life of the Church. Although we are not in favor of a distinct economy of the Spirit as suggested for instance by Vladimir Lossky, ${ }^{14}$ it is justified to accept a different or special role of the Holy Spirit in the divine economy, that of the unity, differentiation, sanctification and completion of the Creation. ${ }^{15}$ By constantly pointing to Christ, the Spirit leads to the final transformation of the whole Creation and human life through his Eucharistic body, a reality that has, as we will see, serious political implications for Christian theology.

\section{Papanikolaou and Kalaitzidis in dialogue: a political theology or a theology of politics}

In the beginning, it is important to give a brief overview of these two books. In the first book entitled The Mystical as Political. Democracy and Non-Radical Orthodoxy, Aristotle Papanikolaou, based on the relational concept of the "divine - human communion", or theosis, guides the readers through various aspects of the Eastern Orthodox tradition (Eusebius, Chrysostom, Sophiology, Zizioulas, Guroian, Yannaras etc.) towards modern debates around the political. This refers especially to the Orthodox attitude against Democracy, the language of human rights, the common good, truth-telling and political forgiveness, as well as the possible contribution of Orthodox recourses to a fruitful engagement in the formulation of political theology. On the other hand Pantelis Kalaitzidis' book entitled Orthodoxy and Political Theology "proposes [in the first place] to examine the reasons for which Orthodoxy has not yet developed a 'political theology," or why "prominent Orthodox theologians have underestimated ...[its] meaning or content." ${ }^{16} \mathrm{He}$ highlights then the eschatological understanding ${ }^{17}$ of the church as the particular contribution of Orthodoxy to political theology, while he follows diverse Orthodox voices from the traditional and the contemporary era and focuses mainly on issues related to the church-state relationship and the public role of the church and its theological discourse.

Although both books explore the possibility of a creative engagement of Orthodoxy in the debates of political theology, and share a more or less

14 See his groundbreaking work entitled: Essai sur la theologie mystique de l'Eglise d'Orient (1944) (English translation, The Mystical Theology of the Eastern Church, 1957). See also: Metropolitan George Khodr, "Christianity in a pluralistic world-The economy of the Holy Spirit" in: The Ecumenical Review 23:2 (1971) p. 118-128.

15 See: Basil Spir. San. 16, PG 32, 136B.

16 See: P. Kalaitzidis Orthodoxy and Political Theology, p. 9-10.

17 Ibidem, p. 89. 
positive conception of the various achievements of post-modernity in this field (for instance a positive reception of the language of human rights or the insistence on the distinct role of the Church in relation to the state, etc.), they follow a different methodology and steps towards their articulation of the frame of an Orthodox political theology. After these important introductory clarifications, it is now time to proceed to a brief, and for this reason schematic, comparative analysis of various aspects of both books, which will help us to understand the role of a theology of the Holy Spirit in their work and in political theology in general.

Context: Papanikolaou is writing his book within the context of the American liberal democracy, and more or less addresses different aspects of this reality in his argumentation. His standpoint then is primarily the Western one, especially North American, with rare references to regimes of South America or the situation in Greece and Russia, etc. On the other hand, Kalaitzidis' context is profoundly European, Western and Eastern, his standpoint and background being the Greek milieu.

Method: Papanikolaou is willing to discuss issues related to modern political debates and to explore the compatibility or incompatibility of Orthodoxy to these issues. His effort, by virtue of the concept of divine-human communion, is to justify politically diverse premises of Orthodox theology, highlighting the "secular," in other words, political relevance of theosis, as the core concept of Orthodoxy throughout the centuries, upon which the incarnation, that is the "in-culturation," of the latter in the World is being desired. Following and extending in this regard the typology put forth by Paul Valliere (that will be discussed below), between "Church Dogmatics" and "Church and World Dogmatics," one could define his method as one of "World Dogmatics," 18 adding thus a third type, where the focus is on the common space (secular-political-public sphere) where the political could meet the theological in a mutually inclusive affirmation. Although the theological character of this proposal lies behind the whole argument, one could counter-argue that it is not necessarily or evidently a Christian perspective, ${ }^{19}$ since the divine-hu-

18 See: Paul Valliere Modern Russian Theology: Bucharev, Soloviev, Bulgakov, Orthodox theology in a new key, Edinburg 2000, p. 306-309. See also: Nikolaos Asproulis, "Is a dialogue between Orthodox theology and (post) modernity possible? The case of the Russian and Neopatristic «Schools»" in: Communio LIV:2 (2012), p. 203-222; idem, " "Church and World Dogmatics». The ecumenical need of a paradigm - shift in the modern orthodox theology and education" in: Review of Ecumenical Studies 5:2 (2013), p. 154-161; idem, " "Church and World Dogmatics» as a new model of theological education: the case of the Orthodox Handbook on Ecumenism" (under publication).

19 See: Vigen Guroian, "Godless theosis" in: Review of 'The Mystical as Political: Democracy and non Radical Orthodoxy', First Things (April 2014), p. 53-55 and the debate in: First Things 
man communion, or literally the concept of theosis, is generally understood as the central goal of the diverse religious and mystical experiences. Kalaitzidis on his side seems to follow a different perspective. Although he is not engaged directly in a dialogue with various aspects of post-modern politics, his primary aim is to search for possible resources in the Orthodox interpretation of the Bible and the patristic tradition that would facilitate the relationship and the creative dialogue between Orthodoxy and political theology. In this light, Kalaitzidis' book seems to follow the method of "Church and World Dogmatics," where the main focus is in expressing an open-ended theological reflection on secular issues (in other words, a kind of systematic theology in the current sense of the term). Despite this quite important methodological differentiation, one could say that both aspects are complementary, even though what is less developed is a closer relationship to the classic "Church Dogmatics" model (namely the grammar of Revelation, history of salvation, etc), something that is more evident in Papanikolaou than in Kalaitzidis. At the same time, although some critiques have insisted on the absence of a strong patristic foundation of Papanikolaou's proposal, ${ }^{20}$ this should not be seen as a sort of weakness, since the patristic heritage should not be used as a depositum of infallible doctrines that can be addressed as ready-made solutions to any issue in every era, something that has been strongly contested by the post-patristic argument in Kalaitzidis' overall thought. ${ }^{21}$ An (Orthodox) political theology however, if it would like to keep in principal its Christian character, needs to take seriously into consideration the very foundation of every Christian theological discourse, which is the grammar of the self-revelation of God

(June/July, 2014), p. 14-15. However the bold criticism put forth by Guroian downplays the overall relevance of the book, since Papanikolaou's distinctively personalist perspective is undoubtedly based and rooted in a divine-human communion in the person of Christ, even if this has not been emphasized as much as it is needed, due to the political intention of the book.

20 Towards this perspective see for instance Oliver O' Donovan, "Review of the "The Mystical as Political»" in: International Journal for the Study of Christian Church 13:1 (2013), p. 7577; Daniel Greeson, "Orthodoxy and Democracy: Compatible after all?” in: Red Egg Review, March 2013 (accessible at http://www.redeggreview.org/book/orthodoxy-and-democracycompatible-after-all/) (last accessed March 15, 2013).

21 See: P. Kalaitzidis, "From the 'Return to the Fathers' to the Need for a Modern Orthodox Theology" in: St. Vladimir's Theological Quarterly, 54: 1 (2010) p. 5-36; idem, "Toward a Post-Patristic Theology?" forthcoming in the proceedings of a very interest conference took place in Volos, June 2010 and organized by the Volos Academy for Theological Studies in cooperation with the Orthodox Christian Studies Program of the Fordham University, the Chair of Orthodox Theology of Munster University and the Romanian Institute for InterOrthodox, Inter-Confessional, and Inter-Religious Studies (INTER) on the general theme: "Neo-Patristic synthesis or Post-patristic theology: Can Orthodox Theology be contextual?" 
in history in the person of Christ. In short, Kalaitzidis' program is closer to a theology of politics, that is a theological interpretation and justification of the political, while in Papanikolaou's argument the reverse perspective is evident, namely the political justification of the theological, which in my view explains better the title of his book ("the mystical as political").

Sources: Both Kalaitzidis and Papanikoloau make use of a rich variety of selected sources in order to develop their argumentation. In both cases, the dominant place is occupied by a strong dependence on Zizioulas' Eucharistic ecclesiology, despite the different way or perhaps focus given to various aspects of his theological program. In addition to this, it is interesting that both share a common interest on Eusebius due to his contribution to the formulation of a political theory of the imperium, although they follow a different reading of his contribution (completely negative in Kalaitzidis; relatively negative in Papanikolaou) and on Yannaras, of whom both are quite critical. On the other hand it is interesting that while there is no reference to Florovsky in Papanikolaou, since the work of the eminent Russian theologian has little to do with political theology, his apprehension of Bulgakov - a theologian almost neglected for various reasons in modern Orthodoxy - is a very positive one. On the other hand, the latter is completely absent in Kalaitzidis' project, while he uses Florovsky at the same time very creatively due to his well-known schematic reading of the relationship between Empire and Desert ${ }^{22}$ (cf. the tension between history and eschata) and his strong historical commitment. In general, the basic sources used by Kalaitzidis are mainly theological (traditional: Bible and the Fathers, and modern Orthodox theologians of the Russian diaspora), while Papanikolaou mostly makes use of the thought of important (Orthodox and Roman Catholics) theologians and political thinkers of recent times (such as J. Zizioulas, Ch. Yannaras, J. Milbank, W. Cavanaugh, etc.).

The basic axis: Looking through the two books, one would very easily realize that the Eucharist, as the very DNA of the ecclesial being, constitutes the fundamental axis upon which both perspectives are founded. In both cases, the Eucharistic ecclesiology of Metropolitan John Zizioulas seems to occupy a central place in their theo-political program. ${ }^{23}$ At the same time, while

22 See: Georges Florovsky, "Antinomies of Christian History: Empire and Desert" in: Christianity and Culture, Collected Works vol. 2, Nordland-Belmont 1974, p. 67-100.

23 For Zizioulas' understanding of the Eucharistic ecclesiology, see among others his "Eucharistic Ecclesiology in the Orthodox Tradition" in: Jean-Marie Van Cangh (ed.), L'Ecclesiologie eucharistique, Academie Internationale des Sciences Religieuses, Bruxelles 2009, p. 187-202; idem, "The Ecclesiology of the Orthodox Tradition" in: Search 7:2 (1984), p. 42-53; idem, "The Ecclesiological Presuppositions of the Holy Eucharist" in: Nicolaus 10 (1982), p. 333- 
Papanikoloau expresses some reservations about different aspects of this ecclesiological model, ${ }^{24}$ such as the sometimes hasty identification between the Kingdom of God and the Eucharist in history, Kalaitzidis bases his whole perspective upon an eschatological emphasis of the Eucharistic understanding of the Church. In this respect he draws on John Zizioulas' perspective although he attempts to avoid the latter's tension towards a close identification between history and eschata. ${ }^{25}$ In this context, Papanikolaou affirms the importance of both Eucharist and ascesis for the realization of the "divine-human communion" in the historical realm, giving greater credit to the ascetical dimension and the relevance of the ascetical practices for the political, while Kalaitzidis' primary emphasis lies on the ecclesial engagement in the political sphere, especially from an eschatological standpoint that secures the dialectical character of the ecclesial way of being, namely the "already/not yet" tension, found in the early Christian consciousness.

The role of pneumatology: Although none of the authors deal explicitly with the role of Pneumatology in their work, one can deduce indirectly whether the Holy Spirit contributes to the formulation of their theo-political perspective. In the case of Kalaitzidis, since the eschatological dimension of the Eucharist seems to be his main focus, the relevance of a theology of the Holy Spirit is quite evident, since it is the Trinitarian person who both constitutes the very being of the Church, and leads to the breaking in of the eschatological Kingdom in History, particularly in the Eucharistic event. As he aptly put it: "any discussion about eschatology leads ineluctably to the question of the church's identity...but also introduces an element of anticipation...the renewing breeze of the Spirit." ${ }^{26}$ Through eschatology, the Holy Spirit more or less forges the link (but also, the distance) between the Church and the World. Eschatology is considered as the very "measure of the authenticity of ecclesial life," which manifests in every time and place "the ... mystery of unity... the overcoming in Christ of every kind of sepa-

49; idem, "L' Eucharistie : quelques aspects bibliques" in: J. Zizioulas, J. M. R. Tillard et al., L' eucharistie, 1970, p. 11-74; see also: Cal. Christiansen, The source of the church: the Eucharistic ecclesiology of John D. Zizioulas and its contribution to the West, Master Thesis (Camarillo, Calif.: St. John's Seminary, 2007); Vitaly Dudkin The pastoral implications of the Eucharistic ecclesiologies of Nicholas Afanasiev and John Zizioulas, Master Thesis (St. Vladimir's Theological Seminary, 2010); James Robert Golka, In service of communion: the Eucharistic eccleciology of John Zizioulas and its implications for ministry, Master Thesis, (Saint Paul Seminary School of Divinity, University of St. Thomas, 1995); Paul McPartlan, The Eucharist makes the church: Henri de Lubac and John Zizioulas in dialogue, Edinburgh, 1993, et. al.

24 See: A. Papanikolaou, The Mystical as Political, p. 81-86.

25 See: P. Kalaitzidis, Orthodoxy and Political theology, p. 89-112.

26 See: P. Kalaitzidis, Orthodoxy and Political theology, p. 89. 
ration and division." ${ }^{27}$ In Kalaitzidis' understanding, the role of the Spirit is that of communion and unity within the Eucharistic event, which images the telos of the history that will be fulfilled in the eschata (cf. Didache). In short, the twofold contribution of pneumatology to political theology, in line with Zizioulas' understanding, is related to that of communion and eschata, as the Eucharistic and eschatological foundation which secures the "sacramental character and depth," in other words the theological, and not ideological, character of the Church's social engagement. ${ }^{28}$ This robust eschatological dimension provides the Church with a necessary "foretaste even now of the life of the future age and the active anticipation in every aspect of life-including therefore, also the social and political..." ${ }^{29}$ It is evident, then, that in this case Pneumatology renders the Church an inclusive community (at least eschatologically) which is open and positive toward the World, but without the compulsory usage of any worldly authoritarian means. On the other hand, in Papanikolaou's work, the role of the Spirit is more implicit and implied in the relevance attributed by him to the Eucharistic ecclesiology (of Zizioulas in particular). Based on the central role of the Eucharistic theology, Papanikolaou credits liberal democracy and generally the political democratic place with the capacity to facilitate the presence of the divine in creation. As he claims, the very "logic of Eucharistic ecclesiology demands the existence of a liberal democratic space," which means in my reading that the Spirit, as the fundamental factor of the Eucharistic event, is active only in the ecclesial community but, if not primarily, in the political sphere, to which the Church is related but does not include or cancel. At the same time, the Holy Spirit seems, according to Papanikolaou, to render liberal democracy as the necessary political space and prerequisite for the flourishing of the Christian Church and its mission in witnessing of the Gospel. Although not without criticism, liberal democracy is considered as the most adequate context for the Church to express itself ad extra and present the soteriological message via persuasion without the fear of any sort of coercion by the state or other community. In other words, the Spirit by acting in the World, and not only in the ecclesial realm, maximizes the very conditions for the public mission of the Church, something that is evidently rooted in the constitution of the Body of Christ, the Church by the Spirit. At the same time, the logic of the "divine-human communion," namely theosis, if

\footnotetext{
27 Ibidem, p. 97.

28 Ibidem, p. 102.

29 Ibidem, p. 106.
} 
it should be understood "in terms of fulfillment of the commandment to love God and neighbour, then it becomes clear that the calling to embody the divine presence more fully in the material creation is not simply to those who flee the World, but also to those who remain in the World," and he will add that "insofar as this ascetics of divine human communion is performed always in relation to the other, then politics must be reconceived as an ascetical practice. ${ }^{\prime 30}$ According to this understanding, since the Holy Spirit assumes the role of uniting the human and divine nature in the person of Christ, it is evident that it is possible to conceive politics as the adequate place where the Holy Spirit contributes to the manifestation of the divine in the material world every time that the democratic longing of the human society is brought to the fore in the light of this "political" ascesis. It seems then, that the principal contribution of pneumatology, as this would be deduced from Papanikolaou's argumentation, is nothing other than the very relational character of being, concerning both created being in general and the political sphere in particular. In this light, Papanikolaou seems to follow the distinctively positive approach of creation put forth by Sophiology and particularly by S. Bulgakov, who spoke of its "sophianity," that is, the divine character of the whole creation which images the divine Sophia. ${ }^{31}$

\section{Pneumatology and politics: A blasphemy or a real relationship?}

Following this introductory comparative and critical comparison of these two promising books on political theology from an Orthodox standpoint, it is now important to argue in favor of the profound and really deep relationship between a theology of the Holy Spirit and the political; by defining clearly the way that pneumatology contributes to the formulation of a genuine political theology.

Since the starting point of doing theology in a biblical, that is Christian, manner is unquestionably the self-Revelation of the Trinitarian God in history, this means that each of the Trinitarian persons is related to the divine economy with a specific role, even though not independently from the others. In this perspective, the Holy Spirit has as its basic work and mission to guide the Creation into its completion, transforming it by bringing in history the Kingdom of God through the constitution of the ecclesial community as the very means and locus where this "New creation" is rendered possible. Therefore, insofar as the self-revelation of God takes place in history and in the

\footnotetext{
30 A. Papanikolaou, The Mystical as Political, p. 196-197.

31 See on this: Aidan Nichols, Wisdom from Above: A Primer in the theology of Father Sergei Bulgakov, Herefordshire 2005.
} 
world, and not exclusively or only in the ecclesial realm, it is evident that the Holy Spirit renders possible for the democratic political sphere, as the most proper worldly context, also to image to some extent the divine, according to the creative purpose of the latter. However, at the same time, while liberal, or some other sort, of democracy on the side of the political is considered as the most adequate structure of social organization, this is not the case on the side of the Church, since the dialectic between history and eschata renders every worldly reality as almost neutral or one can say meaningless, until its eschatological fulfillment or not. In order to avoid any sort of confusion between theology and politics, it is necessary for the Spirit to secure this "already/not yet" biblical tension which safeguards the distinctive character of the ecclesial as well as its close relation to the political and to the Kingdom. It is a new kind of dialectics between the ecclesial and the political, or in G. Florovsky's wording, an antinomy between "Empire and desert" that is implied in the dialectical relation between history and eschata.

Insofar as communion is one of the basic aspects of the work of the Holy Spirit, namely where the Spirit dwells and creates a communion event, then one could argue that both Creation as such in all its aspects but also the Church, as the body of Christ, should be considered as mutually inclusive and open realities, that overcome any sort of exclusivism or negation of the other. Since the Church and the Christian also live in the world, but do not actually belong to this world, it means that, following the personal history of Jesus Christ, both should assume the whole reality (which necessarily includes the social and political realm) in order to transform them as a collective or individual "priest of creation," 32 offering it to the hands of God in Christ by the Spirit. Unless the Spirit is operative, this incarnational dimension and mission of Christian life would not be possible both for Christ himself and the Church, as well as for the ascetical life of each individual Christian. In light of pneumatology, the relational character of being to the extent that it will become reality in history could manifest more or less a glimpse of the divine roots of creation according to its sophianic character. This should not be understood as a continuous immanence of the Spirit in the world, but as a positive reception of the world by the Church and the political by virtue of this indwelling of the Spirit. Otherwise, the Church will become a fixed institution, self-enclosed and self-referential, without the need or the desire to be engaged in the worldly realities that are the result of the creative act of God upon the whole creation and particularly the human being.

32 See: J. Zizioulas, "Preserving God's Creation. Three Lectures on Theology and Ecology" in: King's Theological Review 12 (1989) 1-5, p. 41-45; 13 (1990) 1-5. 
The important role of the theology of the Holy Spirit has tremendous implications in the very theological method. In his now ground-breaking work "Modern Russian Theology: Bukharev, Soloviev, Bulgakov, Orthodox Theology in a New Key, "33 Paul Valliere provides us with a very useful distinction between "Church Dogmatics" and "Church and World Dogmatics." This schematic typology has been used in order to describe the two dominant theological trends in 20th century Orthodox theology, that is, the "Neo-patristic theology" (followed by G. Florovsky, J. Meyendorff, A. Schmemann, J. Zizioulas, etc.) and the "Russian Religious Renaissance" ${ }^{44}$ (V. Soloviev, S. Bulgakov, P. Florenski, etc.). According to my understanding, the concept of "Church Dogmatics" is primarily related to a theology proper (in other words, to a theology ad intra, in terms of classic dogmatics), while the second one - that of "Church and World Dogmatics" - is intended to express an open-ended theological reflection on secular issues (in other words, a kind of systematic theology in the current sense of the term). By virtue of Papanikolaou's book, and following our previous argumentation, one could add one more type to this twofold typology, that of "World Dogmatics." In this case, without downgrading the centrality of theology, one is searching for a common ground (for instance, the concepts of being, experience, divine-human communion, etc.) in order to bring into closer contact (see "correlation", according to Paul Tillich) ${ }^{35}$ and mutual inclusiveness both the Church and the World, but this time from the perspective of the latter. This sort of understanding makes clear the necessarily complementary character of the three perspectives, even though one could start from the second or third without taking explicitly into account the first and vice versa. I think this now threefold typology will be of great importance for our theological methodology, since one can avoid possible polarizations between different perspectives, and also because it manifests a deep dynamic that the Orthodox tradition is able to express by the power of the Holy Spirit.

33 Paul Valliere, Modern Russian Theology: Bukharev, Soloviev, Bulgakov, Orthodox Theology in a New Key, Edinburgh 2000.

34 In this article, I make use of this more or less misleading and even problematic distinction between these two major trends ("Russian" and "Neopatristic," that could hardly be defined in a comprehensive and homogenized manner literally as "Schools") in the Orthodox theology of the $20^{\text {th }}$ century for heuristic purposes.

35 More details in the method of "correlation" see: Paul Tillich, "The Problem of Theological Method II" in: The Journal of Religion, 27: 1 (1947), p. 16-26; D. Kelsey "Paul Tillich", in: David Ford (ed.), The Modern Theologians: An Introduction to Christian Theology in the Twentieth Century, Blackwell 2005, p. 62-75; Bernard Loomer, "Tillich's theology of Correlation" in: Journal of Religion 36:3 (1956), p. 150-156. 


\section{As a way of Conclusion}

As is evident by this brief exploration into the theo-political program of these well-known modern Orthodox theologians, the role of the Holy Spirit in the formulation of a genuine political theology is of great importance, since it seems that its basic tenets would become meaningless without a clear foundation on the distinctive role, on the personal otherness, of the Holy Spirit in the realm of history in the process of the ongoing Heilsgeschichte. 